\title{
Studi Perbandingan Prestasi Belajar Siswa Antara Pemberian Tugas dalam Kelas dengan Pekerjaan Rumah Pada Kelas VII di SMP Negeri 2 Kota Bima
}

\author{
Arif Rahman \\ STKIP Taman Siswa Bima \\ arifbima22@yahoo.com
}

\begin{abstract}
ABSTRAK
Matematika adalah salah satu cabang ilmu pengetahuan yang pada dasarnya dapat dipandang sebagai alat, pola pikir, dan ilmu pengetahuan yang dapat dikembangkan. Penelitian ini bertujuan untuk mengetahui apakah hasil prestasi belajar siswa dengan tugas dalam kelas lebih baik dari pada prestasi hasil belajar siswa dengan pemberian tugas pekerjaan rumah. Hipotesis yang diajukan adalah ada perbedaan yang signifikan antara prestasi belajar siswa antara pemberian tugas dalam kelas dengan pemberian tugas pekerjaan rumah. Untuk mengguji hipotesis diambil sample dari populasi yang dilakukan secara random. Sebagai populasi adalah siswa kelas VII Semester II di SMP Negeri 2 Kota Bima tahun pelajaran 2017/2018. Sampel yang diambil adalah dua kelas, dan setiap kelas masingmasing terdiri dari 38 orang. Metode pengumpulan data yang digunakan adalah berbentuk tes tertulis. Tes diberikan pada saat pokok bahasan sudut dan garis telah selesai. Tes ini digunakan untuk mengetahui apakah perlakuan terhadap kelas eksperimen telah memberikan hasil yang lebih baik dibandingkan kelas kontrol. Untuk keperluan ini digunakan uji t-tes. Setelah dilakukan perhitungan terhadap skor tes akhir diperoleh rata-rata tes akhir dari kelas eksperimen yaitu, 6,9 dan rata-rata tes akhir kelas control yaitu, 6,1. Setelah dilakukan uji t-tes tehadap kedua kelas ternyata t-hitung $>$ t-tabel $(5,369>1,994)$ dengan taraf signifikan $5 \%$, sehingga hipotesis yang diajukan diterima.
\end{abstract}

Kata kunci: Tugas dalam Kelas, Tugas Pekerjaan Rumah, dan Prestasi.

\section{PENDAHULUAN}

Pendidikan berperanan penting dalam kehidupan manusia. Karena untuk mencetak kader-kader pemimpin yang profesional harus melalui program pendidikan. Jadi pada hakikatnya dunia pendidikan ini menyiapkan siswa agar mampu memecahkan berbagai problem kehidupan. Oleh karena itu perbaikan dan pengembangan-pengembangan demi tercapainya mutu pendidikan mutlak diperlukan. Seorang guru harus memperhatikan pemilihan metode yang tepat untuk mengajarkan materi suatu pelajaran. Sebagaimana kutipan berikut "metode mengajar itu mempengaruhi belajar" (Slameto, 2010: 65).

Salah satu karakteristik pendidikan matematika ditinjau dari segi proses adalah belajar dan bekerja. Hal ini berarti dalam belajar matematika perlu disertai dengan mengerjakan soal-soal latihan yang ada kaitannya dengan materi yang sedang dipelajari yang umumnya berbentuk pemberian tugas. Pemberian tugas pekerjaan rumah adalah pemberian tugas yang dikerjakan di rumah. Tapi pada kenyataanya pekerjaan rumah seringkali dikerjakan di kelas dengan cara menyalin pekerjaan milik temannya tanpa mengalami peristiwa belajar. Adakalanya tugas itu dikerjakan oleh orang lain. Ini adalah kelemahan pemberian tugas dirumah. Kelemahan ini menyebabkan pemberian tugas dirumah kurang efektif sebagaimana diharapkan. Untuk itu pengalihan dari tugas rumah ke tugas kelas perlu dilakukan. Karena bila siswa diberi tugas dalam kelas maka guru dapat berperan sebagai pengawas dan pemberi saran sehingga dapat mengantisipasi adanya kerjasama untuk pelaksanaan tugas berlangsung. Dalam pelaksanaan pembelian tugas dalam kelas diharapkan siswa memperoleh suatu ketangkasan atau keterampilan latihan terhadap apa yang telah dipelajari, sehingga latihan-latihan tersebut merupakan suatu proses belajar mandiri dalam kelas. Pada saat pembuatan tugas di kelas siswa diperbolehkan membuka buku atau 
catatan tetapi tidak diperbolehkan untuk bekerjasama dengan siswa lain.

Berdasarkan permasalahan yang telah diuraikan tersebut, peneliti tertarik untuk meneliti dengan menguji perbedaan prestasi belajar siswa antara pemberian tugas dalam kelas dengan pemberian tugas pekerjaan rumah. Penelitian ini bertujuan untuk mengetahui: (1) Ada tidaknya perbedaan prestasi belajar antara pemberian tugas dalam kelas dengan pemberian tugas pekerjaan rumah; (2) Manakah yang lebih baik prestasi belajar antara pemberian tugas dalam kelas dengan pemberian tugas pekerjaan rumah pada materi pokok Sudut dan Garis kelas VII semester II di SMP Negeri 2 Kota Bima tahun pelajaran 2017/2018.

\section{METODE PENELITIAN}

Jenis penelitian yang digunakan dalam penelitian ini adalah jenis penelitian eksperimen. Penelitian eksperimen adalah penelitian yang diadakan dengan cara peneliti sengaja membangkitkan suatu kejadian atau keadaan. Kemudian diteliti hasilnya, atau dengan kata lain peneliti mencari hubungan sebab akibat antara dua faktor yang sengaja ditimbulkan oleh peneliti sendiri. Jadi dalam penelitian ini data dikumpulkan setelah semua kejadian yang sengaja dipersoalkan berlangsung.

Pendekatan yang digunakan dalam penelitian ini ditinjau dari timbulnya variabel pada umumnya dibagi dua yaitu pendekatan noneksperimen dan pendekatan eksperimen. Sudjana dan Ibrahaim (2002:19) menjelaskan bahwa yang dimaksud dengan pendekatan ekspeimen adalah pendekatan dimana peneliti dengan sengaja dan secara sistematik mengadakan perlakuan variabel dalam peristiwa alamiah, kemudian mengamati konsekuensi perlakuan tersebut. Jadi pendekatan yang digunakan adalah pendekatan kualitatif karena gejala yang diteliti yaitu prestasi belajar siswa yang diberikan tugas dalam kelas dengan siswa yang diberi tugas pekerjaan rumah pada materi pokok sudut dan garis sengaja diadakan atau dirancang untuk melihat perbedaanya

Subjek dalam penelitian ini adalah seluruh siswa kelas VII semester II di SMP Negeri 2 Kota
Bima tahun ajaran 2017/2018. Jadi populasi yang diambil dalam penelitian ini adalah siswasiswa kelas VII. Pengambilan populasi ini berdasarkan pertimbangan yang logis antara lain: keperaktisan, sesuai dengan kemampuan, (terbatasnya; waktu, biaya, dan tenaga). Karena tidak semua data dan informasi akan diproses dan tidak semua siswa akan diteliti melainkan cukup dengan menggunakan sampel yang mewakilinya. Setelah populasi ditentukan, selanjutnya peneliti menentukan sampel. Riduwan (2010:11) mengatakan bahwa, "Sampel adalah bagian dari populasi yang mempunyai ciri-ciri atau keadaan tertentu yang akan diteliti”. Dari kutipan tersebut barulah peneliti dapat menentukan sampel dalam penelitian ini.

Dalam penelitian ini terdapat dua macam variabel. Kedua variabel tersebut adalah pemberian tugas dalam kelas dan pembeian tugas dalam rumah. Berdasarkan fungsinya maka variabel penelitian ini dibedakan menjadi: Variabel bebas adalah variabel yang mempengaruhi dan biasanya disebut dengan penyebab (Suharsimi Arikunto, 2002: 101). Yang menjadi variabel bebas dalam penelitian ini adalah pemberian tugas dalam kelas dan pemberian tugas di rumah. Sedangkan variabel terikat adalah suatu hasil yang dicapai atau akibat dari variabel bebas (Suharsimi Arikunto: 2002: 101). Yang menjadi variable terikat dalam penelitian ini adalah prestasi belajar.

Dalam penelitian ini penulis menggunakan metode penelitian eksperimen dengan rancangan penelitian sebagai berikut:

$\mathrm{X} \rightarrow \mathrm{T}$ kelas yang diberi tugas dalam kelas.

$\mathrm{Y} \rightarrow \mathrm{T}$ kelas yang diberi tugas pekerjaan rumah.

Keterangan :

$\mathrm{X}$ : Pemberian tugas dalam kelas

$\mathrm{Y}$ : Pemberian tugas pekerjaan rumah

$\mathrm{T}:$ Tes (tugas)

Pelaksanaan penelitian dengan: (1) Memberi perlakuan $\mathrm{X}$ terhadap kelas yang diberikan tugas dalam kelas dan perlakuan Y terhadap kelas yang diberi tugas pekerjaan rumah; (2) Memberi T setelah siswa diberi pengajaran materi pokok sudut dan garis. (3) Membandingkan hasil $\mathrm{T}$ 
kelas yang diberi tugas dalam kelas dan hasil $\mathrm{T}$ kelas yang diberi tugas pekerjaan rumah.

Dalam penelitian ini metode yang digunakan dalam pengumpulan data adalah dengan menggunakan metode tes subjektif. Untuk keperluan tersebut dibutuhkan instrumen penelitian. Instrumen penelitian adalah alat atau fasilitas yang digunakan oleh peneliti dalam mengumpulkan data agar pekerjaan lebih mudah dan hasilnya lebih baik dalam arti cermat, lengkap, dan sistematis sehingga lebih mudah diolah (Arikunto, S: 1998: 151). Oleh karena itu seorang guru sudah sewajarnya menggunakan tes yang dapat mengetahui kemampuan peserta didik. Teknik analisis data adalah tata cara yang diikuti dalam menganalisis data untuk mengambil suatu kesimpulan. Ada beberapa cara yang harus di tempuh dalam menganalisis data dalam penelitian ini, yaitu: (1) Uji Homogenitas; (2) Uji Validitas; dan (3) Uji t-tes (Sugiyono, 2011).

\section{HASIL PENELITIAN}

Dalam pelaksanaan penelitian ini secara garis besar dapat dibagi dalam beberapa tahap pelaksanaan yaitu sebagai berikut: (1) Uji Homogenitas. Untuk menetukan pada populasi tersebut homogen peneliti menggunakan uji homogenitas, dengan ketentuan; Jika $\chi_{\text {nut }}^{2} \geq \chi_{t_{1}}^{2}$, maka tidak homogen.Jikal $\chi_{n u}^{2} \leq \chi_{t_{1}}^{2}$, maka homogen. Setelah dilakukan uji homogenitas, maka populasi tersebut homogen. Jadi peneliti dapat menentukan sampel penelitian. (2) Penentuan Sampel. Dalam penentuan sampel dipilih secara acak (random sampling). Sehingga kelas yang dipilih sebagai sampel dalam penelitian ini adalah kelas VIIC dan kelas VII G, dimana kelas VII G sebagai kelas eksperimen yang diberi perlakuan $\mathrm{X}$ yaitu kelas yang diberikan tugas dalam kelas, dan kelas VIIC sebagai kelas kelas kontrol yang diberi perlakuan Y yaitu kelas yang diberikan pekerjaan rumah. (3) Uji Validitas Tes. Sebelum peneliti melakukan pelaksanaan kegiatan belajar mengajar, peneliti terlebih dahulu melakukan uji tes kevalitan pada tiap butir soal yang akan diberikan. Berdasarkan uji validitas soal dengan menggunakan rumus product moment dari 30 soal hanya 19 soal tes yang valid dan 11 soal yang tidak valid. Soal-soal tesebut dikatakan valid karena r-hitung $\geq r$ tabel, sedangkan soal yang tidak valid dikarenakan r-hitung $\leq$ r-tabel. (4) Pelaksanaan Kegiatan Belajar Mengajar. Setelah dilakukan uji validitas, barulah peneliti melakukan proses pembelajaran pada kedua kelas tersebut. Perlakuan yang diberikan pada kedua kelas tersebut berbeda dalam memberikan tes. (5) Pengumpulan Data. Adapun pengumpulan data dalam penelitian ini dilakukan dengan cara memberikan tugas pada pertemuan kedua dan ketiga serta diberikan perlakuan berbeda pada masing-masing kelas. Hal tersebut dilakukan karena melihat dari tujuan yang ingin dicapai. Peneliti menyusun 19 soal yang ada kedalam 8 soal yang disesuai dengan materi yang diberikan. Soal-soal tersebut dibagi dalam dua pertemuan. Pertemuan kedua diberikan 3 soal dan pada pertemuan ketiga diberikan 5 soal. soal-soal pada pertemuan ketiga dibuat dalam bentuk lembaran dan disertakan kertas jawabanya sehingga siswa dapat memiliki waktu yang cukup untuk mengerjakannya. Hal ini dilakukan karena pada pertemuan kedua siswa kelas VIIG mengalami kekurangan waktu untuk mengerjakan tugas di kelas dan kelas VIIC banyak yang tidak mengumpulkan tugasnya. Sedangkan waktu yang diberikan untuk menjawab tes di kelas adalah 2 x 45 menit, dan untuk pekerjaan rumah 24 jam. Dan hanya hasil pada pertemuan ke-3 yang digunakan untuk dianalisis. (6) Analisis data. Data yang telah dikumpulkan kemudia dianalisis. Hasil analisis ditampilkan pada tabel berikut:

Tabel 1. Analisis Data Prestasi Belajar Siswa Pada

Pelajaran Matematika Antara Siswa Kelas yang

diberikan Tugas di dalam Kelas dengan Siswa yang diberikan Tugas Pekerjaan Rumah

\begin{tabular}{ccccc}
\hline $\begin{array}{c}\text { Jumlah } \\
\text { Siswa }\end{array}$ & Kelas & $\begin{array}{c}\text { Nilai } \\
\text { Rata-rata }\end{array}$ & t-hitung & t-tabel \\
\hline 37 & Eksperimen & 6,9 & \multirow{2}{*}{5,369} & 1,994 \\
\hline 39 & Kontrol & 6,1 & & \\
\hline
\end{tabular}

Berdasarkan analisis data dapat diperoleh $t$ hitung > t-tabel. Ini berarti hipotesis (Ho) yang diajukan, yaitu tidak ada perbedaan prestasi matematika antara siswa yang diberi tugas dalam kelas dengan yang diberi tugas pekerjaan rumah 
pada siswa kelas VII semester II di SMP Negeri 2 Kota Bima tahun pelajaran 2017/2018 ditolak, berarti hipotesis alternatif $(\mathrm{Ha})$ diterima yaitu, ada perbedaan prestasi belajar matematika antara siswa yang diberikan tugas dalam kelas dengan siswa yang diberikan tugas pekerjaan rumah pada kelas VII semester II di SMP Negeri 2 Kota Bima tahun pelajaran 2017/2018.

\section{PEMBAHASAN}

Berdasarkan analisis data yang diperoleh bahwa nilai thitung sebesar 5,369 lebih besar dari nilai t-tabel sebesar 1,994. Ini menunjukan bahwa ada perbedaan prestasi belajar matematika antara siswa yang diberikan tugas dalam kelas dengan siswa yang diberikan tugas pekerjaan rumah pada siswa kelas VII semester II di SMP Negeri 2 Kota Bima tahun pelajaran 2017/2018. Pada hasil tes akhir pada siswa kelas eksperimen yang diberi tugas dalam kelas, terlihat nilai rata-rata sebesar sebesar 6,9. Sedangkan hasil tes akhir pada siswa kelas kontrol yang diberi tugas pekerjaan rumah, terlihat nilai rata-rata sebesar 6,1. Jadi dengan demikian sudah jelas bahwa nilai rata-rata kelas eksperimen lebih tinggi dibandingkan nilai ratarata kelas kontrol. Pada hasil perhitungan uji tes antara siswa yang diberi tugas dalam kelas dengan siswa yang diberikan tugas pekerjaan rumah bahwa nilai maksimal antara kelas eksperimen dan kelas kontrol berbeda. Begitu juga dengan nilai minimum dari kedua kelas tersebut berbeda.

Faktor yang menyebabkan kelas eksperimen yang diberi tugas pekerjaan dalam kelas lebih baik adalah karena siswa memperoleh suatu ketangkasan atau keterampilan latihan terhadap apa yang telah dipelajari. Sehingga latihanlatihan tersebut merupakan suatu pelajaran mandiri dalam kelas. Metode pelajaraan tugas dalam kelas juga memungkinkan adanya pertanyaan secara langsung dari siswa kepada guru jika tugas diberikan itu kurang jelas. Sehingga proses belajar saling berkesinambungan dan tidak setatis. Pemberian tugas pekerjaan rumah juga bermanfaat bagi siswa untuk mengulang kembali materi pelajaran yang telah dipelajari di sekolah, tetapi siswa menyalahgunakan hal tersebut, sehingga pada kenyataannya pekerjaan rumah seringkali dikerjakaan di sekolah atau di kelas dengan cara menyalin pekerjaan milik temannya tanpa mengalami peristiwa belajar. Adakalanya tugas itu dikerjakan oleh orang lain.

\section{KESIMPULAN}

Berdasarkan hasil penelitian yang diperoleh, dapat disimpulkan bahwa: (1) Ada perbedaan yang signifikan prestasi belajar siswa antara pemberian tugas dalam kelas dengan pemberian tugas pekerjaan rumah pada materi pokok sudut dan garis kelas VII semester II di SMP Negeri 2 Kota Bima tahun pelajaran 2017/2018. Hal ini dapat dilihat berdasarkan perhitungan uji $\mathrm{t}$ dari data yang telah diambil bahwa t-hitung $>\mathrm{t}$-tabel $(5,369>1,994)$. Sehingga hipotesis yang diajukan yaitu Ho ditolak dan Ha diterima; (2) Prestasi belajar pemberian tugas dalam kelas lebih baik dari pada prestasi belajar pekerjaan rumah. Hal ini dapat dilihat pada pembahasan dan analisis data yang diproleh bahwa nilai rata-rata kelas eksperimen yaitu 6,9 lebih besar dari nilai ratarata kelas kontrol yaitu 6,1 .

\section{DAFTAR PUSTAKA}

Arikunto, S. (1998). Prosedur Penelitian Suatu Pendekatan Peraktek, Jakarta: Rineka Cipta. Arikunto, S. (2002). Prosedur Penelitian, Jakarta: Rhineka Cipta.

Riduwan. (2010). Belajar Mudah Untuk Karyawan dan Peneliti Pendidikan. Bandung: Alfabeta.

Slameto. (2010). Belajar Dan Faktor-faktor yang Mempengaruhinya, Jakarta: Rhineka Cipta.

Sudjana, Ibrahim. (2002). Metode Dan Analisis Penelitian, Bandung: Tarsito.

Sugiyono. (2011). Statistik Untuk Penelitian. Bandung: Alfabeta. 